\title{
Land Discourses, Patronage, And The 2018 Village Election In Baleharjo, Yogyakarta
}

\author{
Fikri Disyacitta ${ }^{1}$, Darnik Wulandari ${ }^{2}$, and Anastasia I. Cahyaningrum ${ }^{3}$
}

Received: 3 May 2019 | Accepted: 22 November 2019 | Published: 18 December 2019

\begin{abstract}
This article explores how village chief candidates can utilise a suburban community's understanding of public land use to mobilise political support, taking as its example the village chief election in Baleharjo, Yogyakarta, Indonesia. This article argues that, where village residents still rely on land for their welfare, candidates can politicise land grievances to gather popular support. In Baleharjo, the incumbent received the backing of merchants and investors from predominantly non-agrarian pedukuhan (hamlets) who felt that they had benefitted from the use of village-controlled land for tourism purposes. At the same time, the challenger recognised the hardships of farmers who had been deleteriously affected by such use of village-controlled land, and thus mobilised them on voting day. Applying a qualitative approach, data for this article were collected through interviews and participatory observation over the course of October 2018.
\end{abstract}

Keywords: land, land grievances, village elections, patronage, suburban

\section{Introduction}

This article explores the repurposing of village-controlled land within the context of voter mobilisation, taking as its example the 2018 village election in Baleharjo, a sub-urban village in Gunung

1 Fikri Disyacitta is a doctorate student at Department of Politics and Government, Universitas Gadjah Mada. He has written numerous academic journal articles, opinion columns in mass media, book chapters, and focusing on elections, food politics, and urban politics. He may be contacted at: fikridisyacitta@gmail.com

2 Darnik Fatimah Wulandari is a fresh graduate of Departement of Politics and Government and research assistant at the Research Centre for Politics and Government (PolGov), Faculty of Social and Political Sciences, Universitas Gadjah Mada. This is her first research publication and interested in issues of elites, local politics, elections and resource politics. She may be contacted at : D.fatimahw@gmail.com

3 Anastasia Imelda Cahyaningrum is a research assistant at Research Centre for Politics and Government (PolGov), Faculty of Social and Political Science, Universitas Gadjah Mada. She has participated in various studied of border issues, women issues, and elections. She may be contacted at: imeldaningrum.ai@gmail.com . 
Kidul Regency, Yogyakarta Province. This election was contested by two candidates, both of whom were wealthy entrepreneurs, and both of whom campaigned on a platform of utilising villagecontrolled land to promote prosperity and improve public welfare. By studying the politicisation of village-controlled land as a club good in village elections, this article shows the importance of land in village politics, particularly as a club good for vote buying (Aspinall \& Sukmajati, 2015). Studies by Wiradi \& Tjondronegoro (1984), Priyatmoko (2017), and Pranoto (2017) have shown that, in Java's agrarian villages, the legitimacy of a village chief depends on that individual's ability to transparently distribute village-controlled land (known in Indonesian as tanah kas desa and in Javanese as bondo deso) to improve public welfare; however, these three studies have yet to link the management of village-controlled land to electoral contestations. Meanwhile, D'Arcy \& Nistotskaya (2019) have shown that presidential candidates in Kenya have effectively politicised land distribution and use to mobilise electoral support, wooing tribes (each with its own specific interests) by promising them land for agriculture and settlement in exchange for their votes. However, despite noting the correlation between land politicisation and the mobilisation of voters, this study examines a national (presidential) election, and as such necessitates 'distance' between candidates and the land grievances they mobilise. Unlike at the smaller scope, such as at the village level, candidates do not directly experience voters' grievances or feel the effects of land politicisation.

This article focuses on specifically on the politicisation of village-controlled land in a suburban village. Bintarto (1969) identifies suburban villages as sharing several key characteristics. First, these villages are characterised by proximity to urban centres. Second, as a consequence of the first characteristic, residents of suburban villages have access to diverse livelihoods (rather than being limited to agriculture as in rural villages) and thus levels of land commercialisation are higher. Third, suburban villagers tend to have higher levels of education, and as tend to understand 
the value of land than their less educated peers. Owing to these characteristics, urban, suburban, and rural villages have their own unique socio-cultural characteristics, and their residents are likewise different. However, as shown by Yandri (2017) and Yuningsih \& Subekti (2016), studies of Indonesia's suburban villages have yet to explore the political dimensions of the land they control or their chiefs' politicisation of land to mobilise voters.

Yandri (2017) argued that the low level of suburban voter participation in a South Tangerang local election could be attributed to residents being commuters employed in nearby cities and regencies. As such, voters prioritised their jobs over the elections. Furthermore, they believed that their lives would be unaffected by the outcome of the election; as they earned their livelihoods elsewhere, local economic empowerment programmes would be ineffective. Meanwhile, Yuningsih \& Subekti (2016) investigated the high level of electoral competition in 'Cimekar', which they characterised as a transitional village (one bordering an urban centre and combining rural and urban characteristics). Candidates were motivated to contest the village election because they sought to control-and therefore benefit from-the hectares of village-controlled land (both wet and dry). As such, they were willing to utilise a range of strategies, including money politics. However, despite studying land in village politics, neither explored the use of village-controlled land to mobilise voters in village elections.

Recognising its potential to contribute to academic discourse, the case of Baleharjo Village, Gunung Kidul Regency, Yogyakarta Special Administrative Region, Indonesia, offers an interesting case. The literature has shown that Javanese villages traditionally have two types of communal land that is passed from administration to administration, namely village-controlled land (tanah kas desa) and administrator-controlled land (tanah lungguh). Villagecontrolled land refers to land that is controlled collectively by a village's government and residents, and as such contributes to the village coffers. Meanwhile, administrator-controlled land refers 
to the land that is provided to the village chief in lieu of wages, through which the village chief earns an income. Owing to their economic strategicness, both types of land can become viable political commodities. In Baleharjo, these types of land have both been managed and politicised by village elites during electoral contestations. This has been complicated by the suburban nature of Baleharjo, which increases the value and commodifiability of the land. In this village, as seen in its 2018 election, local residents have been polarised in their understandings of how to manage communal land, their ideals being shaped by candidates.

On the one hand, residents who earn their livelihoods through agricultural means continue to prioritise the agricultural use of village-controlled through a rental system. Meanwhile, entrepreneurs, village administrators, and others with experience managing economic assets have sought to transform non-productive land into markets, tourist attractions, or other facilities with more tangible effects on the village economy. During the 2018 Baleharjo election, this polarisation was exploited by both the incumbent and the challenger to mobilise political support.

Given this background, this article seeks to understand how candidates politicised the management of village-controlled land for their own electoral purposes. It is organised as follows. First, it introduces the topic and identifies its research problem. Second, it offers a review of the literature and discusses land grievances as its theoretical framework. The third section is divided into two parts, exposing the socio-historic context of Baleharjo and its particular issues with village-controlled land. Fourth, it describes Baleharjo's 2018 election, including the use of money politics as a manifestation of political patronage and as an electoral strategy. Fifth, it analyses the election-particularly the politicisation of land issues - from a land grievances perspective. Finally, it presents its conclusions. 


\section{Land and General Elections: A Land Grievances Perspective}

Studies in multiple countries have explored village land as a political resource that is used strategically to contest elections. In Pakistan, for example, landlords running for parliament have promised to reduce their land rental fees if farmers give them electoral support (Beg, 2014). In Fiji, although the politicisation of land issues was relatively ineffective, it was still used by two parties in the 2014 election to gain voter support; both parties focused on the land rights of indigenous peoples, the Taukei, vis a vis the rights of migrants (Sakai, 2015). Such cases show that political elites in developing countries, particularly those with land access and ownership, can use this land to gain the support of voters who are economically dependent on land. However, both of the above studies limited their discussion to national elections.

Mainland China, meanwhile, has provided specific lessons about the link between communal land and village elections. For example, Yao (2009) showed that the mechanisms of village elections create spaces where diverse interests can intersect to promote candidates' electoral victory; farmers tend to support candidates who are committed to revitalising collective agricultural land, while local party elites usually back candidates who do not threaten party interests. In the case studied by Yao, both interests were supported by one particular candidate, who ultimately won the village election. O'Brien \& Han (2009), meanwhile, found that the election of committee members in Chinese villages is not only vulnerable to super-structural intervention (i.e. from the state and from regional party elites), but also to internal community dynamics such as clan interests and the mobilisation of local strongmen during times of conflict-including land disputes that occur during elections. As such, democratisation has been stymied. Both of these studies have shown that problems with collective land can influence voters' electoral choices. However, neither study has provided a theoretical framework that is capable of explaining how 
land is politically commodified by village elites during their electoral contestations and creation of support bases.

For a theoretical understanding of how communal land is used to mobilise public support during elections that is relevant to Baleharjo, one may reference a study of land grievances in Africa conducted by Klaus \& Mitchell (2015). They recognised that land grievances are used strategically by political elites through discourses of injustices in land distribution and access, often resulting in violence. More theoretically, they argued that-when democratisation and state commitment to land ownership are limited-political elites have the opportunity to exploit the situation to organise mass support, and may even cite injustice as a reason for perpetrating electoral violence. However, communities are not only agitated by political elites, but also have their own claims to land ownership (Geschiere, in Klaus \& Mitchell, 2015), at times citing ancestral land ownership or government policies regarding disputed land.

Klaus \& Mitchell argued that two logics function simultaneously when political elites use communal land issues within electoral contexts. First is the logic of land insecurity, through which political leaders convince potential voters that violations of (positive and traditional) law and injustices in the distribution of land have benefited migrants over indigenous people. Through such a logic, political leaders emphasise the loss of communal land and the resulting economic and political disenfranchisement. Elections, thus, are viewed as threatening, and the electoral defeat of propeople candidates is framed as perpetuating and exacerbating the marginalisation of the common people. Rumours that indigenous people will be driven away from communal land, as well as collective memories of previous exoduses, intensify in the weeks before elections. In such situations, acts of violence against political opponents is seen as the only viable means of escape.

Second is the logic of contested land claims, through which political elites promise to provide greater land, offer material 
incentives, and reinforce communal land rights to win elections. Consequently, supporters are not only willing to participate in electoral processes, but also to commit violence against opposing candidates and their (perceived) supporters during the election, as they perceive such practices as necessary to guarantee their preferred candidate's electoral victory. Generally, this second logic is more viable when employed by people with the real power to provide and/or protect special land rights. Figure 1 below provides a general understanding of how land grievances function within electoral contexts.

Figure 1. Forms of Land Grievances (and their connection with village elections)

\begin{tabular}{|c|c|c|}
\hline Grievances & Electoral Logic & Potential for Violence \\
\hline $\begin{array}{c}\text { Discourse of } \\
\text { Land Insecurity } \\
\text { "The government has } \\
\text { stolen communal land } \\
\text { from us and given it } \\
\text { to outsiders" }\end{array}$ & $\begin{array}{l}\text { Logic of } \\
\text { Land Insecurity } \\
\text { Elections will only } \\
\text { benefit those who are } \\
\text { stealing communal land. } \\
\text { If a political opponent } \\
\text { wins the election, } \\
\text { indigenous peoples will } \\
\text { be driven away from the } \\
\text { land that provides their } \\
\text { livelihood. }\end{array}$ & $\begin{array}{l}\text { Electoral violence } \\
\text { is committed before } \\
\text { or after elections } \\
\text { to prevent the } \\
\text { electoral defeat of the } \\
\text { supported candidate } \\
\text { or the exodus of } \\
\text { indigenous peoples. }\end{array}$ \\
\hline $\begin{array}{c}\text { Discourse of } \\
\text { Contested Land Claims } \\
\text { "Our ancestral lands } \\
\text { have been taken over } \\
\text { by outsiders." }\end{array}$ & $\begin{array}{l}\text { Logic of } \\
\text { Opportunity } \\
\text { Electoral mechanisms } \\
\text { provide the local people } \\
\text { with the opportunity to } \\
\text { reclaim their communal } \\
\text { land or reassert their } \\
\text { existing rights. }\end{array}$ & $\begin{array}{l}\text { Electoral violence } \\
\text { is committed against } \\
\text { political opponents to } \\
\text { ensure the electoral } \\
\text { victory of the candidate } \\
\text { who has promised } \\
\text { that rights over } \\
\text { communal land will } \\
\text { not be transferred to } \\
\text { outsiders. }\end{array}$ \\
\hline
\end{tabular}


Furthermore, according to Klaus \& Mitchell (2015, p. 626), where political elites have the power to distribute, redistribute, and provide access to communal land to their constituents while excluding their opponents, and/or can manipulate existing institutions and laws to do so, they have paternalistic power. In such cases, supporters will generally believe candidates' electoral promises and remain loyal to them. Conversely, when candidates are perceived as lacking the political power to (re)allocate land, potential voters will reconsider the need for violence, believing that they would not be properly remunerated for such acts.

The authors, however, have adapted this theory of land grievances based on their research findings. The model proposed by Klaus \& Mitchell holds that the politicisation of land grievances, both through the logic of land insecurity and through the logic of contested land claims, will ultimately result in electoral violence being used to promote a specific agenda. This argument was criticised by Fearon \& Laitin (2003), who-through their study of land disputes in Latin America-showed that the politicisation of land grievances does not necessarily result in political or electoral violence. This is reaffirmed by the current study, which finds that candidates' politicisation of village-controlled land in the 2018 Baleharjo election did not result in electoral violence.

\section{Baleharjo: Socio-Historic Background and Problems Socio-Historic Background}

An administrative territory located along National Road III, merely one kilometre from the Wonosari District Offices and the Gunung Kidul Regency Office Complex, Baleharjo may be characterised as a suburban village. Certain pedukuhan (sub-village administrative units), such as Purwosari, are quasi-urban, housing such facilities as the Office of the State Attorney and the Regional Police Station; the village is also home to various economic facilities, such as banks, cooperatives, shops, and the Former 
Terminal Market. ${ }^{4}$ However, other parts of the village maintain rural characteristics, with broad expanses of agricultural land being found in Gedangsari, Wukirsari, and Rejosari.

The demographics of Baleharjo reflects its suburban characteristics. Of its 5,853 residents, 620 work as entrepreneurs, 354 as private-sector employees, and 206 as farmers or farm labourers (Gunung Kidul Regency Government, 2017). Owing to its socioeconomic characteristics, Baleharjo cannot be identified as a rural village within the typology offered by Mulyanto (2009). Unlike true rural villages, residents are not limited to agriculture for their livelihoods. Rather, they rely predominantly on non-agricultural means to support themselves. At the same time, however, Baleharjo is not truly urban, as agriculture and agricultural land remain prominent in the village.

Baleharjo was historically known as Besole. Village leaders were not chosen democratically. Rather, leadership roles were occupied by persons deemed to have supernatural powers (kesaktian) (Lestari, interview, 8 October 2018). Most of these leaders, including Ki Atmowijoyo, were illiterate. After Indonesia's independence, Besole was renamed Baleharjo, and in 1946 the nascent national government-seeking to facilitate governance-decreed that all village chiefs must be able to read and write. As such, Barjo Yuwono was chosen to succeed the illiterate Kiyai Karto Pawiro as village chief of Baleharjo, ultimately serving until his death in 1986.

Political dynasties have been relatively insignificant in Baleharjo. Only two of Barjo Yuwono's children subsequently became village chief. The first of these, Agus Sutarjo, served as acting village chief for two years after his father's death before being officially elected in 1988. After Sutarjo's leadership ended with his death in 1991, none of Barjo's children served as village chief until 2002, when Barjo's son Ircham Mawardi was elected.

One of Agus Sutarjo's daughters, Tri Hastuti, serves as the

So named because it is located on the site of the former Baleharjo Bus Terminal. 
head of dukuh of Purwosari; in 2010, several constituents urged her to contest the election, believing that she had the correct skills and lineage to lead the village (Hastuti, interview, 12 October 2018). However, she refused, citing both the burden of leadership and the widespread superstition that Baleharjo's village chiefs are unable to complete full terms in office. According to local belief, if a village chief dies in office, this is evidence of poor performance and problematic leadership. One village elder stated that only an honest and sincere leader could complete a full term (Adigomo, interview, 10 October 2018).

Ultimately, the 2010 election was won by Agus Setiawan, a local chicken feed entrepreneur who managed the restaurant "Jodhang Jowo". Setiawan had previous practical political experience, being a cadre of the Nasdem Party (Partai Nasdem). Before and during his first term in office, which lasted until 2016, he established paternalistic networks with village youths and local strongmen (Setiawan, interview, 30 October 2010; Tugiyanto, interview, 8 October 2018). These networks proved beneficial in his electoral contestations and his governance. For example, Budi Susilo, a strongman who had held power over the Baleharjo Bus Terminal, used intimidatory practices to convince travellers to support Setiawan (Susilo, interview, 29 October 2018). In return, Setiawan provided shirts and uniforms to village youths - particularly in Mulyosari, his main support base.

During Baleharjo's 2018 election, Agus Setiawan ran for a second term. His opponent was Agus Sulistyo, an entrepreneur who had become wealthy through his welding activities in the pedukuhan of Rejosari. Although he had no experience with practical politics, Agus Sulistyo had significant social capital, including (through his father) strong networks in the pedukuhan of Gedangsari, linkages with wealthy entrepreneurs, and good relations with the congregation at Al-Fatah Mosque in the pedukuhan of Wukirsari (Suratman, interview, 13 October 2018). Ultimately, Setiawan won the 2018 Baleharjo election. Interestingly, Agus Setiawan's electoral 
victory belied the belief that no village chief could complete a full term-let alone be re-elected.

\section{Land, a Source of Problems}

The creation and strengthening of linkages between local government elites and investors has transformed the systems through which land is managed and utilised, thereby resulting in widespread commercialisation. Anseeuw (in Hennings, 2015) has shown that, on the one hand, local governments have provided investors with economic incentives and easier land use regulations. Investors, meanwhile, have promised economic growth, job opportunities, and infrastructural development. However, land is not only an economic and developmental asset; it is an important part of communities' cultural and historical identities (United Nations, 2012). Over the long-term, the commercialisation of land can cause significant environmental issues, transform socio-cultural structures, and marginalise political communities; as such, it is often met with resistance (Hennings, 2015). When formal institutions lack the power to minimise conflict, land claims become increasingly political (Hennings, 2015)

This theoretical argument can guide our understanding of the unique phenomena in Baleharjo. In the past five years, conflict and corruption in the management of village-controlled land have been rampant. This is not surprising, given the suburban character of the village. Residents who earn their livelihood through agriculture require land, especially the fertile land controlled by the village. At the same time, however, rapid infrastructure development has caused the land prices to increase drastically, and as such the village government can receive more immediate benefits if it uses agricultural land for non-agricultural purposes. For example, land along National Road III (which cuts through the pedukuhan of Purwosari, Rejosari, and Wukirsari) sells for Rp 1,700,000 Rp 2,000,000 per square meter, several order of magnitude more 
than more remote land (much of which sells for Rp 50,000 to Rp 100,000 per square metre). Consequently, the taxable value of land can increase quickly, up to $10 \%$ per annum; this puts a significant financial burden on local residents (Safrudin, interview, 29 October 2018).

However, the rapid increase of land prices and strategic location of Baleharjo have not been accompanied by programmes and village enterprises that promote the public welfare (Puspitasari, interview, 12 October 2018). Village governments can benefit from high land prices, renting lands to third parties with the expectation that said parties will employ locals and improve their welfare. The rental fees received, meanwhile, can be deposited in the village coffers and utilised to fund physical and social development. However, in Baleharjo, this has not occurred; rather, high land prices have been exploited for personal benefit. Projects and programmes utilising village-controlled land have not been transparent, and a number of cases of abuse have occurred. In 2009, acting village chief Bejo Raharjo was found to have embezzled approximately $\mathrm{Rp} 70,000,000$ from money paid as remunerations for land used to build a waste disposal site (Kejaksaan Republik Indonesia, 2013).

In 2014, during Agus Setiawan's first term, the Baleharjo Village Government and the Gunung Kidul Regency Government came into conflict over the land upon which the Gunung Kidul Bus Terminal had been built. The village government believed that it was being paid too little for the rental of this village-controlled land, and thus Agus Setiawan mobilised his constituents to block the road into the terminal (Setiawan, interview, 7 October 2018). In this manner, he managed to force the regency government into negotiations. Ultimately, they decided jointly to move the terminal to Selang Village. In its place, the village government built a new market, entrusting its management to CV Karya Lancar; this company belonged to Sumaryo, one of Setiawan's cronies (Safrudin, interview, 29 October 2018).

According to the incumbent, Sumaryo had been facing 
bankruptcy. As such, he had given his crony-through his company CV Karya Lancar - the opportunity to invest in and manage the market. Sumaryo built 50 stalls, with merchants charged $\mathrm{Rp}$ $20,000,000$ for a lifetime rental as well as $\mathrm{Rp} 1,000,000 /$ month to cover taxes, maintenance, and security. Meanwhile, Sumaryo was required to contribute $\mathrm{Rp} 2,000,000,000$ to the village coffers; this gave him permission to operate the market for twenty years. In its first year of operations, the market contributed Rp 200,000,000 to the village coffers (Setiawan, interview, 7 October 2018). Unfortunately however, the dukuh of Purwosari (where the market is located) was not involved in the market's development; as such, its economic activities have not contributed to the coffers of the pedukuhan (Hastuti, interview, 12 October 2018).

Another land dispute began in 2015, after Agus Setiawan and six other village administrators decided to repurpose eight hectares of administrator-controlled land in the pedukuhan of Gedangsari. To avoid any legal complications, this land was converted to villagecontrolled land before being sold to a third party: PT Prima Inti Natura (PIN), a developer based in Bandung. Upon this land, the village administrators planned to build the Jogja Education Park (JEP), promising constituents that they would prioritise local residents in all hiring, mercantile, and operational activities. Village administrators, meanwhile, would share JEP's profits (Sutrisno, interview, 9 October 2018); they viewed this as more profitable than using the land for agricultural purposes (Suatmi, interview, 4 October 2018).

Conflict broke out after PT PIN began using heavy equipment to excavate land that was still productive; the company had yet to socialise its plans, and it had begun its activities when during a harvest season (Tugiyanto, interview, 10 October 2018). Farm labourers, most of whom lived in Gedangsari, protested the excavation, but were received poorly; PT PIN argued that it was the village government's duty to socialise the repurposing of this land. The following day, the company-seeking to prevent protests and 
incursions - surrounded the disputed land with barbed wire. This dispute was exacerbated when PT PIN failed to meet deadlines and initiate its project by the end of 2016. As the project continued to be delayed, rumours spread that the incumbent had embezzled money (Setiawan, interview, 7 October 2018).

The village government also came under investigation for its construction of the Baleharjo Village Hall, which had been completed in 2014 (Susilo, interview, 29 October 2018). The State Attorney of Gunung Kidul identified this project, worth an estimated Rp 1,400,000,000, as having lacked transparency and suspected that funds had been embezzled by the village chief. The village government, however, identified the project as having been funded through the proceeds of the former terminal market (Wibawa, interview, 9 October 2018).

Ultimately, when Setiawan sought re-election, these cases were simultaneously framed as opportunities and as obstacles. As such, they required careful management to ensure electoral victory.

\section{The 2018 Baleharjo Election: Strategies, Contestations, and Results}

During Indonesia's New Order, village elites depended heavily on state patronage to maintain their power. Although Indonesia has entered a new era of democracy, Aspinall \& Rohman (2017) have argued that village elites still rely on super-village actors-perhaps even more intensely than before. This argument is confirmed in the case of Baleharjo, where both candidates established linkages with political parties and investors. As this section will show, these linkages also influenced their politicisation of communal land issues. Two candidates, both wealthy entrepreneurs, contested Baleharjo's 2018 election: the incumbent Agus Setiawan and the challenger Agus Sulistyo.

Second on the ballot, Agus Setiawan had more experience with practical politics than his opponent. In 2009, he had unsuccessfully 
contested the Gunung Kidul legislative election, having run with the Marhaenist National Party of Indonesia (Partai Nasional Indonesia Marhaenisme). He later mobilised his support base to contest the 2010 village election (Susilo, interview, 29 October 2018). Towards the end of his first term as village chief, Setiawan was made deputy chairman of the Nasdem Party's branch committee. In 2015, he served as a political broker for Benyamin Semanu, a resident of Semanu Village who contested Gunung Kidul's executive election as an independent candidate; ultimately, more than $90 \%$ of Baleharjo's residents voted for Semanu (Sulistyo, interview, 28 October 2018). Although Semanu did not win the election, he and Setiawan continued to maintain a close relationship. As such, when the village government was searching for investors to develop its land in Gedangsari, Semanu was the one who connected Setiawan with PT PIN (Safrudin, interview, 29 October 2018). The incumbent also had close relationships with village youths and strongmen, particularly in the pedukahan of Mulyosari (his main support basis). Acting as a local patron, he incorporated them into his campaign team; to maintain their loyalty, he provided them with incentives such as "gas money", free lunches, and even-on nights before they hung campaign posters-copious amounts of alcohol (Setiawan, interview, 30 October 2018).

Unlike the incumbent, Agus Sulistyo-who was first on the ballot-lacked any significant experience with practical politics. Before contesting the election, he had only served as a neighbourhood administrator in Rejosari; as such, he relied significantly on his family, particularly his father's social networks in the pedukuhan of Gedangsari (Sulistyo, interview, 8 October 2018). Nonetheless, he was able to convince Budi Susilo, a former strongman and deputy chairman of Nasdem Youth's Gunung Kidul branch, to coordinate volunteers in Wukirsari. Having backed Setiawan in Baleharjo's 2010 election, Budi was disappointed by the incumbent's failure to provide irrigation to his lands near the Wukirsari Waste Disposal Site (Susilo, interview, 28 October 2018). The relationship between 
Budi and Sulistyo was paternalistic (Aspinall \& Sukmajati, 2015), and inexorably linked to land issues; Budi promised that he would get Sulistyo at least $40 \%$ of votes in Wukirsari, and in exchange the challenger would ensure that his land was provided with proper irrigation (Susilo, interview, 28 Oktober 2018). Ultimately, however, Sulistyo was unable to defeat Setiawan; the incumbent received 1,911 votes to the challenger's 1,598 .

Rumours of money politics, particularly vote buying, spread widely during the village election. According to Kennedy (2009), money politics tends to be more common in suburban villages, as residents see the provision of money and goods during elections as normal and natural - especially when candidates are newcomers to politics and lack the political capital and linkages of the incumbent. To an extent, this is supported by the case of Baleharjo. Sulistyo prepared campaign funds of $\mathrm{Rp} 500,000,000$, which he borrowed from his parents, parents-in-law, and siblings, and planned to distribute $\mathrm{Rp} 100,000$ to each potential swing voter in the days before the election (Muntari, interview, 28 October 2018). However, this plan was ultimately not executed, as the challenger desired to win the election cleanly, on his own merit.

Rather, it was Setiawan who massively used money politics to undermine the challenger's main support bases, namely the pedukuhan of Rejosari (where Sulistyo lived) and the Al-Fatah Mosque congregation in the pedukuhan Wukirsari (Sulistyo, interview, 28 October 2018). In Rejosari, each neighbourhood administrator was given $\operatorname{Rp} 1,000,000$ and asked to mobilise support for the incumbent; for every swing voter swayed, a neighbourhood administrator would receive $\mathrm{Rp}$ 200,000 (Muntari, interview, 28 October 2018). Meanwhile, to reach members of the Al-Fatah Mosque congregation, money-between $\mathrm{Rp} 300,000$ and $\mathrm{Rp}$ 500,000 per voter - was distributed after morning prayers on the day of the election (Muntari, interview, 28 October 2018). Owing to this unexpected practice of money politics, the challenger lost both of these pedukuhan (Susilo, interview, 29 October 2018). 
Although this practice of money politics received widespread attention, disputes over two pieces of village-controlled land were central in Baleharjo's 2018 election. Where Kennedy (2009) argued that suburban village elites access communal village-controlled land to recoup their financial investments in elections, in this case the incumbent utilised his experiences with two parcels of villagecontrolled land to access voter support, with a particular focus on the land upon which the Baleharjo Bus Terminal had stood.

Meanwhile, Sulistyo's campaign volunteers-who identified themselves collectively as the "M1 Volunteers" (Relawan M1) focused their discussions on the scandals that had plagued the incumbent during his first term. These volunteers optimistically believed that suspected embezzlement in the construction of the village hall, which had resulted in part from the lack of transparency in the repurposing of the former terminal land, would deleteriously affect the incumbent's electability. During one all-night campaign discussion (known popularly as lek-lekan), Budi reminded these volunteers to not count their chickens before they hatched; suspected corruption was not enough. So long as embezzlement had not been proven, it was better to avoid speculation and focus on backing the challenger (personal communication, 8 October 2018).

Two weeks after the election, it was found that the merchants had supported the incumbent en masse. This confirmed Budi's suspicion that, even though the lack of transparency was public knowledge, it would not be enough to undermine Setiawan's reelectability. Sumaryo, who had invested in the market and continued to manage it, had continued to provide Agus Setiawan with access to merchants. Sulistyo, who was related to Sumaryo's first wife, recognised the man's campaign experience and skill.

"For legislative candidates, Maryo had decades of experience. He was an investor in the former terminal. He had joined him (the incumbent). From when I was in elementary school, junior high school, he had been helping legislative candidates. So he was politically mature... He, see, he had money, and ties with the elected village chief. If any problems arose, 
they'd both be affected"5 (Sulistyo, interview, 28 October 2018).

In an interview, a village administrator familiar with local governance and land issues confirmed that Sumaryo had politically supported the incumbent during the election. He confirmed that this local investor, who had family ties with the head of dukuh of Mulyosari, had supported the incumbent to guarantee his continued right to manage the market - or even to access future village projects.

"As an entrepreneur, Maryo participated too. Meaning that he supported (the incumbent, ed.). So now his position is strong, with access to land. 'If I'm given a project...' So, he can say, 'I'd like a permit to make this.' [And the incumbent will say] 'Please do'. It can't be denied that politics and business are linked, even at the village level"' (Safrudin, interview, 29 October 2018).

In return for village projects and access to village-controlled land, Sumaryo mobilised the market's approximately 100 merchants in support of the incumbent. Using his personal funds, this local investor also provided batik uniforms to the merchants.

"Him, the boss, the one who backed me in the village election, he promised the people. The elders that Maryo gathered then, he'd give them batik. Now he has. There were a hundred people, but I didn't have to spend any money. Maryo had been a contractor, but been facing insolvency... I wasn't given anything, [but] during the election he backed me up. ... He called people together, asked them, 'Do you still support the chief or not. If you support him, I'll buy you all uniforms.' Now it's happened. Now, he (Sumaryo, ed.) has bought (batik uniforms for the merchants, ed.). All I had to do was sit by his side."7 (Setiawan, interview, 30 October 2018).

5 Original: Kalau untuk urusan caleg, Pak Maryo itu sudah berapa puluh tahun. Dia itu investor yang di eks terminal. Dia 'kan ikut sana (petahana-pen.). Sejak saya SD sampai SMP itu dia sudah ikut caleg. Jadi secara politik itu matang...Dia 'kan sebagai orang yang berduit, ada ikatannya sama lurah yang terpilih. Kalau pun kasus ya kena berdua.

6 Original: Sebagai pengusaha kemarin Pak Maryo ' $k a n$ ikut juga. Dalam arti ikut mendukunglah (petahana-pen.). Jadi sekarang enak, punya tanah, 'Kalau saya dikasih proyek', nah. 'Saya mengajukan ijin saya mau bikin ini', 'Iya, silahkan'. Tidak bisa dipungkiri antara politik dengan bisnis, walaupun di tingkat desa saja sudah main.

7 Original: Ini, bosnya yang kemarin back-up saya di pilkades, ini kan janji di masyarakat. 
However, such material incentives were deemed insufficient to guarantee merchants' continued support, and as such the incumbent's volunteers chose to use intimidatory tactics. This was experienced by Nanok, a merchant who sold nuts and other crops in the rear part of the market. During the campaign, the phrase "nang Jodhang Jowo opo Sekar Kusuma" (at Jodhang Jowo or Sekar Kusuma?) became widely used to identify residents' political affiliation (Nanok, interview, 14 October 2018). While dealing with a harvest, Nanok was approached by several of the incumbent's campaign volunteers. One of them, wrapping his arms around Nanok's shoulders, asked the merchant why he had not attended a meeting and meal at Jodhang Jowo. Although this question was asked without any anger or threatening tones, Nanok felt intimidated; he thus answered that he had told his son Wawan to attend the meeting in his stead. "It's a meeting for youths, and I'm old. I told Wawan to go (to Jodhang Jowo)" (Nanok, interview, 14 October 2018). After this visit, the research team observed that Nanok had begun actively attending campaign meetings and meals sponsored by the incumbent. Together with his son Wawan, Nanok visited Agus Setiawan on election day and received some "money for cigarettes". Nanok did not only experience intimidation, however. He also felt himself indebted to the incumbent, as the construction of the market had enabled him to relocate. Previously, he had operated a

Orang-orang tua yang dikumpulkan Pak Maryo kemarin, mau dikasih batik. Sekarang sudah dibelikan. Ada seratusan orang lho, tapi saya malah tidak keluar uang. Pak Maryo itu 'kan dulu pemborong, tapi sempat mau bangkrut...Saya ini tidak dikasih apa-apa ... Cuma waktu pilkades ini diback-up sama dia... Mengumpulkan orang untuk ditanting, istilahnya, ditanya kamu masih mendukung pak mantan tidak? Kalau kamu mendukung pak mantan, kamu semua tak belikan seragam. Sekarang jadi, dia (Sumaryo-pen.) belikan (seragam batik untuk pedagang-pen.). Padahal saya cuma menunggu di sampingnya.

8 Before Baleharjo's 2018 election, this question was used associatively to determine a person's political leanings. Jodhang Jowo is a restaurant owned by the incumbent Agus Setiawan, and was used by his campaign team for its meetings and discussions. Meanwhile, Sekar Kusuma is the restaurant in which the challenger Agus Sulistyo consolidated his campaign team and planned his strategies. As such, residents could determine one's political affiliations by their answer to the question. 
roadside stall, an illegal operation that nonetheless required him to pay $\mathrm{Rp} 2,000,000 /$ month to a landlord. As such, by voting for Agus Setiawan, he hoped that the market could continue to be developed, thereby improving his quality of life.

Also influential in the election was the scandal over the village administrator-controlled land in Gedangsari. Both village administrators and the challenger recognised this case as a major hurdle for the incumbent, particularly in Gedangsari (Safrudin, interview, 29 October 2018; Susilo, interview, 29 October 2018; Tugiyanto, interview, 8 October 2018). As stated previously, the residents of Gedangsari-most of whom earned a living as nut and onion farmers - had been the most deleteriously affected by the construction of JEP. This was exacerbated by the fact that this land had been seized less than a month before the harvest, and the company failed to provide them with renumerations (Utomo, interview, 28 October 2018).

Responding to this case, thirty-two farmers from Gedangsari established Tunas Harapan as a vehicle for the farmers and farm labourers in the pedukuhan. They hoped that, through this organisation, they could submit a petition to the district government and formally object to the repurposing of village land for JEP. However, this petition was never sent. Members believed that their organisation was too small, too dominated by older farmers, and too limited in scope to have a significant effect; furthermore, they feared that any such petition would only create enmity and unrest in the village (Hartono, 28 October 2018). As such, Tunas Harapan had no significant influence or ability to articulate its members' interests. Instead, members turned to Sulistyo as an alternative leader, hoping that -if he were elected - he would restore this land for agricultural use (Utomo, interview, 28 October 2018).

Indeed, when speaking with these farmers, Sulistyo frequently used the slogan "Restoring the Assets of Baleharjo". Ultimately, although he lost the election, Sulistyo won significantly more votes than the incumbent (418 to 195). As such, it may be surmised 
that this land dispute significantly and detrimentally affected the incumbent's electability.

\section{Land Grievances in a Suburban Village}

Observations in the field indicated that communal land (village-controlled land and village administrator-controlled land) remains an important resource in suburban Baleharjo. Secondary sources, supported by interviews, show that-although most suburban villagers earn their livelihood through non-agricultural means - their desire for investment (such as tourism and market projects) nonetheless gives them an interest in local land and its use. In Gunung Kidul, the tourism sector has developed rapidly; as seen in Table 1, the Original Local Government Revenue produced by the regency's tourism industry increased significantly between 2013 and 2017. Such economic growth was tantalizing for village elites, and likely a factor in their decision to construct a major tourism attraction in the village.

Table 1. Original Local Government Revenue, Tourism Sector, Gunung Kidul (2013-2017)

\begin{tabular}{|c|c|c|c|c|c|}
\hline \multirow{2}{*}{ Regency } & \multicolumn{5}{|c|}{ Original Local Government Revenue (Rp) } \\
\hline \multirow{3}{*}{$\begin{array}{c}\text { Gunung } \\
\text { Kidul }\end{array}$} & 2013 & 2014 & 2015 & 2016 & 2017 \\
\cline { 2 - 6 } & $8,168,857,392$ & $17,415,255,577$ & $24,107,812,555$ & $28,375,385,566$ & $32,758,748,570$ \\
\hline
\end{tabular}

Source: Dinas Pariwisata Daerah Istimewa Yogyakarta (2017)

On the other hand, however, farmers and farm labourers in Baleharjo - particularly in the pedukuhan of Gedangsari-continue to perceive land as agricultural.

In the 2018 Baleharjo village election, both the incumbent 
and the challenger sought to utilise these two aspects of suburbanity as political capital and as means of getting voters' support. As also seen in China, villagers tended to support the candidate who was more financially established, had a clearer vision for village welfare, and - through connections with supralocal actors - could facilitate access to development projects (Bernstein, 2006). At the same time, however, and even as Baleharjo became increasingly urbanised, farmers and farm labourers generally refused to vote for a village chief with a track record of misusing communal land, often (they argued) to the detriment of the village's welfare.

Both of the candidates who contested Baleharjo's 2018 election were wealthy entrepreneurs who hoped to use existing resources-particularly land-to promote village welfare and who had established supralocal networks. However, they differed significantly in their level of access to supralocal actors and their real paternalistic power, including the power they used to politicise land grievances as a means of mobilising voters. Conceptually, patronage is defined as distribution of material or immaterial benefits to individuals - voters, employees, campaign staff, or even supralocal actors - in return for their political support (Shefter in Sukmajati \& Aspinall, 2015). The good distributed may include money, projects, or individual/community goods.

According to Boone (2011), politicians who desire to mobilise political support often use their land as a paternalistic resource. They can, for example, promise to provide voters with access to this land as remuneration for their political support during elections. In such cases, electoral contestations are also competitions for land and land access.

In his first term, Setiawan had employed a logic of contested land claims to manifest his vision of public welfare. For example, through his decision to transform the former bus terminal into a market, he became popular among merchants and was perceived as seeking to improve their welfare. Claiming the right to control this land was not easy; indeed, in 2013 Setiawan and his supporters had 
blockaded the road into the long-dormant terminal after the regency government chose to reactivate it (Setiawan, interview, 30 October 2018; Hastuti, interview, 12 October 2018). The village and regency governments thus entered negotiations, and ultimately agreed that the village government would have the right to administer this land and seek investors who were willing to build a market.

Also during his first term, Setiawan established concrete paternalistic relationships by giving his crony Sumaryo the right to manage the new market. Having personally benefitted from the repurposing of this land through his company CV Karya Lancar, Sumaryo mobilised his clients (i.e. the merchants at the market) in support of his patron during the 2018 Baleharjo election. Merchants such as Nanok, meanwhile, believed that the incumbent had taken concrete measures to improve their welfare and quality of lifein this case, by allowing them to use village-controlled land for mercantile activities. They hoped that, by voting for the incumbent, they would continue to be allowed to rent stalls and profit from them. Hoping to guarantee Setiawan's electoral victory, thereby securing his right to manage the village-controlled land, Sumaryo even promised to use his own funds to provide new batik uniforms to one hundred merchants.

The farmers and farm labourers of Gedangsari who backed Sulistyo had different experiences. They were disappointed by Setiawan decision to invite PT PIN to exploit the former village land, his failure to socialise this information among residents, and the company's destruction of their harvest. Furthermore, as the company had failed to complete JEP within the promised time, the villagers had not received the promised benefits. Sulistyo and his campaign team thus created the discourse that the incumbent had arrogantly taken away the land on which they depended without even informing them. He promised to "Restore the Assets of Baleharjo", exploiting the traumatic memory of the company's use of bulldozers on their harvests and arguing that the incumbent would be unable to improve farmers' quality of life. 
Furthermore, despite lacking the patronage networks of the incumbent-who controlled the village administration and legal apparatuses, and enjoyed good relationships with investorsSulistyo promoted a broad agenda. Farmers and farm labourers, while recognising that the challenger had limited political experience, believed that he could restore the village-controlled land they had been using.

Sulistyo convinced the farmers and farm labourers that he was the rational choice, as it would ensure that the incumbent was not reelected and enable them to regain access to village-controlled land. Nonetheless, belying the arguments of Klaus \& Mitchell (2015), logic of land insecurity did not result in electoral violence. Analysing data from the field, it is apparent that the challenger's relative lack of paternalistic power, as well as limited incentives, supporters were unwilling to employ violence as an electoral strategy.

A map of the candidates' use of patronage and land grievances to mobilise mass support in Baleharjo's 2018 election is provided in Figure 2 below.

\section{Figure 2. Land Grievance Discourses Utilised by Candidates to Mobilise Support in Two Disputed Areas}

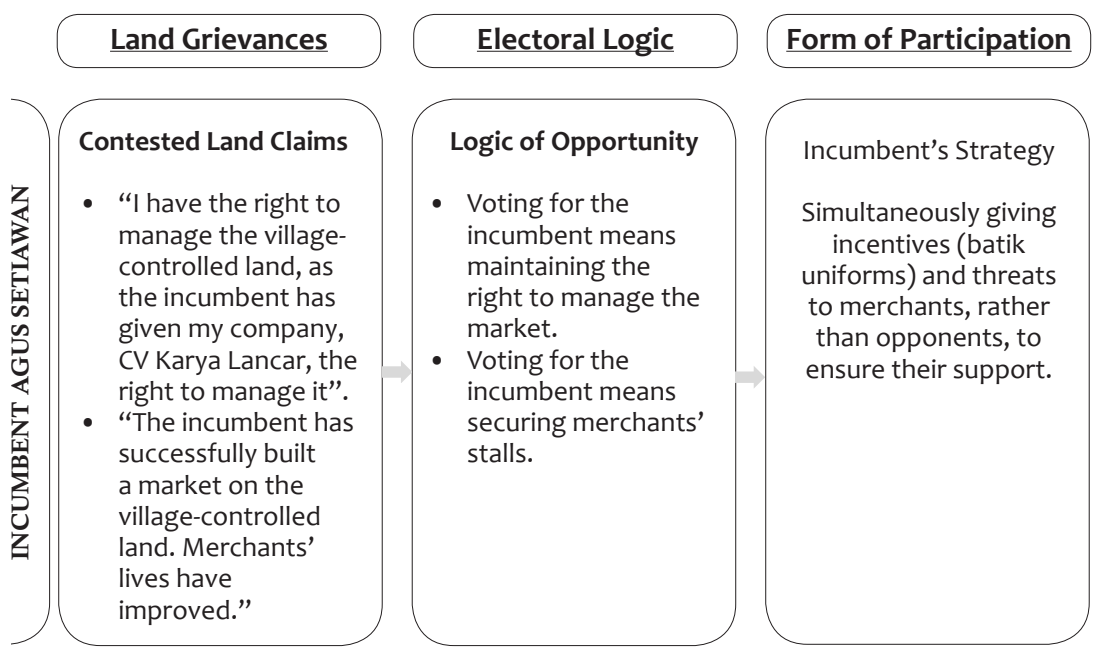



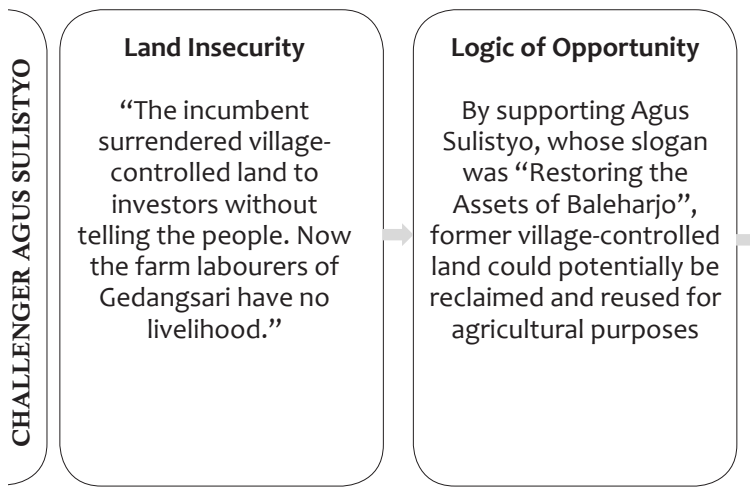

$$
\begin{aligned}
& \text { Electoral violence not } \\
& \text { practiced; electoral } \\
& \text { participation framed as } \\
& \text { a means of punishing } \\
& \text { the incumbent } \\
& \text { for perceived } \\
& \text { transgressions. Little } \\
& \text { reward for violence. }
\end{aligned}
$$

\section{Conclusion}

The experiences of Baleharjo show that, in suburban villages that are characterised demographically by residents earning their livelihood through either agrarian or non-agrarian means, villagecontrolled land is a public good and strategic resource that can be politically exploited to advance candidates' electoral interests. Exploiting land grievances and offering particular visions of land use, such as for agriculture or investment, is crucial in such cases. Through the logic of contested land claims, Agus Setiawan was able to win Baleharjo's 2018 election and mobilise the merchants of the local market. In this, he benefitted from his past leadership activities. By transforming a non-productive bus terminal into a functional market, the incumbent improved the welfare of local merchants, and they in turn felt a debt of honour that could only be repaid through their votes. Patronage was also important, as it enabled him to maintain the support bases that he required to contest the village election. This could be seen, for example, when he guaranteed a quid pro quo exchange with a local investor: the investor would mobilise merchants in his support, and in return said investor would continue to enjoy and exercise the right to manage the market. Merchants, in turn, were driven to support the incumbent through a combination of land claims, material incentives (i.e. batik uniforms), and intimidation. 
Meanwhile, when the incumbent failed to use the villagecontrolled land in Gedangsari to realise his vision of public welfare, demobilisation occurred; this was exacerbated by his administration's use of repressive approaches. Such an opportunity was exploited by the challenger, Agus Sulistyo, who-despite lacking the paternalistic power of the incumbent-was able to exploit the logic of land insecurity and grievances of local farmers to gather their support. Ultimately, he won Gedangsari by a large margin.

Through these findings, this article has strengthened the argument that land grievances are an effective means of mobilising voters in suburban villages. It is hoped that these findings can help create new space for academic discourse regarding the electoral processes of suburban villages. 


\section{References}

Aspinall, E., \& Rohman, N. (2017). Village head elections in Java: Money politics and brokerage in the remaking of Indonesia's rural elite. Journal of Southeast Asian Studies, 48(1), 31-52. Retrieved from https://www.researchgate.net/publication/312960800.

Aspinall, E., \& Sukmajati, M. (2015). Politik uang di Indonesia: Patronase dan klientelisme pada pemilu legislatif 2014. Yogyakarta: PolGov.

Bernstein, T. P. (2006). Village democracy and its limits. ASIEN, 99, 2941. Retrieved from http://asien.asienforschung.de/wpcontent/ uploads/sites/6/2018/05/ASIEN_99_Bernstein.pdf.

Bintarto, H. R. (1969). Geografi desa. Yogyakarta: Spring.

Boone, C. (2011). Politically allocated land rights and the geography of electoralviolence: Thecase of Kenyainthe1990s. Journalof Comparative Political Studies, 44(10), 1311-1342. Retrieved from https://journals. sagepub.com/doi/abs/10.1177/0010414011407465.

Dinas Pariwisata Daerah Istimewa Yogyakarta. (2018). Statistik Kepariwisataan 2017. Retrieved from https://visitingjogja.com/ downloads/Buku-Statistik-Kepariwisataan-DI-Yogyakartatahun-2017.pdf

D'Arcy, M., \& Nistotskaya, M. (2019). Intensified local grievances, enduring national control: The politics of land in the 2017 Kenyan elections. Journal of Eastern African Studies, 13(2), 294-312. Retrieved from https://www.tandfonline.com/doi/full/10.1080/17531055.2 019.1590763 ?af $=\mathrm{R}$.

Fearon, J. D., \& Laitin, D.D. (2003). Ethnicity, insurgency, and civil war. The American Political Science Review, 97(1), 75-90. Retrieved from https:// journals.sagepub.com/doi/pdf/10.1177/0022343315580145.

Hennings, A. (2015). Resistance against large-scale land acquisitions: Bougainville's peace process under threat? In Land Grabbing, Conflict and Agrarian $\square$ Environmental Transformations: Perspectives from East and Southeast Asia. Chiang Mai: BRICS Initiatives for Critical Agrarian Studies (BICAS).

Kennedy, J. J.(2009). The price of democracy: Vote buying and village elections in China. Asian Politics and Policy, 2(4), 617-631. Retrieved from https://www.researchgate.net/publication/228154010_The Price_of_Democracy_Vote_Buying_and_Village_Elections_in China.

Klaus, K., \& Mitchell, M. I. (2015). Land grievances and the mobilization of electoral violence: Evidence from Cote d'Ivoire and Kenya. Journal of Peace Research, 52(5). Retrieved from https://journals. 
sagepub.com/doi/pdf/10.1177/0022343315580145.

Mulyanto, D. (2009). Kapitalisasi dalam penghidupan perdesaan. Bandung: Yayasan Akatiga.

O'Brien, K. J., \& Han, R. (2009). Path to democracy? Assessing village elections in China. Journal of Contemporary China, 18(60), 359-378. Retrieved from http://dx.doi.org/10.1080/10670560902770206.

Kejaksaan Republik Indonesia (2013, August 26). Kejari Wonosari Menahan Pj Kades Baleharjo. Kejaksaan Republik Indonesia. Retrieved from https://www.kejaksaan.go.id/berita. php?idu $=3 \&$ id $=8130 \&$ hal $=387$

Pranoto, C. B. (2017). Pembangunan negara, hukum pertanahan Indonesia, dan kembalinya tanah kasultanan di Yogyakarta. Jurnal Politik, 3(1), 21-51. Retrieved from http://jurnalpolitik.ui.ac.id/index.php/jp/ article/view/49.

Priyatmoko, H. (2017). Konflik tanah bengkok di pedesaan Jawa kontemporer. Jurnal Bhumi, 3(1), 35-50. Retrieved from http:// jurnalbhumi.stpn.ac.id/index.php/JB/article/view/225.

Sakai, S. (2015). Insecurity of Taukei land as an issue in the 2014 general election: Real threat or political gimmick?. The Journal of Pacific Studies, 35(2), 49-64. Retrieved from https://core.ac.uk/download/ pdf/77223365.pdf.

United Nations. (2012). Land and conflict. Retrieved from https://www. un.org/en/land-natural-resources-conflict/pdfs/GN_ExeS_ Land\%20and\%20Conflict.pdf.

Wiradi, G., \& Tjondronegoro, S. M. P. (1984). Dua abad penguasaan tanah: Pola pengusaan tanah pertanian di Jawa dari masa ke masa. Jakarta: Gramedia.

Yandri, P. (2017). The political geography of voters and political participation: Evidence from a local election in suburban Indonesia. Indonesian Journal of Geography, 49(1), 57-64. Retrieved from https://jurnal.ugm.ac.id/ijg/article/view/11315/pdf.

Yao, Y. (2009). Village elections and redistribution of political power and collective property. The China Quarterly, 197, 126-144. Retrieved from https://www.jstor.org/stable/27756426?seq=1\#page_scan_ tab_contents .

Yuningsih, N. Y., \& Subekti, V. S. (2016). Demokrasi dalam pemilihan kepala desa? Studi kasus desa dengan tipologi tradisional, transisional, dan modern di provinsi Jawa Barat tahun 2008-2013. Jurnal Politik, 1(2), 231-261. Retrieved from http://jurnalpolitik. ui.ac.id/index.php/jp/article/download/21/53. 